\title{
Teleconsultation: an Integrative Review of the Doctor-Patient Interaction Mediated by Technology
}

\section{Teleconsulta: uma Revisão Integrativa da Interação Médico-Paciente Mediada pela Tecnologia}

\author{
Soraia de Camargo Catapan ${ }^{\mathrm{I}}$ \\ Maria Cristina Marino Calvo ${ }^{\mathrm{I}}$ (D)
}

\section{KEYWORDS}

- Teleconsultation.

- Telemedicine.

- Remote Consultation.

- Patient Care.
Medical teleconsultation can apply different technologies to mediate the communication between doctors and patients located in different geographic spaces. Its implementation has been encouraged in several countries, under the assumption of its potential to overcome distances, offering health care in a shorter time, reducing costs and workload. The scarcity of evidence about these allegations, in addition to the need of clarifying the situations in which teleconsultation can be adequate, safe and effective, have generated debates, intensified after the publication of Resolution N. 2.227/2018 by the Federal Council of Medicine, which allowed medical teleconsultation, containing principles and recommendations. This article aims to analyze the international experience of medical teleconsultation, including the media and technologies employed, their use, benefits and limitations, highlighting and associating the controversial points of the resolution recently published by the Federal Council of Medicine. An integrative review of the literature was carried out to identify these experiences from January 2013 to February 2019. Of the 1912 identified references, 42 were analyzed after applying the exclusion and inclusion criteria. Data collection and analysis indicated that telephone, e-mail, e-consulting systems, video or a combination of those have been used in several countries to mediate the doctor-patient relationship. Its use goes ranges from diagnosis to treatment, monitoring, management and prescription, both in acute and chronic conditions. The main benefits include less demand for face-to-face consultations, with the possibility of doctors' workload management, allowing systems' reorganization. Moreover, the teleconsultation allows overcoming distance barriers, in a flexible and convenient way for patients, possibly contributing to continuity of care, patient autonomy and resource savings, in the latter case, when it avoids work absenteeism due to face-to-face consultation. Some limitations of the teleconsultation include the inability to perform the physical examination, so it is not recommended for the first consultation. Technical and communication difficulties for each media, as well as its inadequacy for some groups of patients, are other important barriers. Data security regarding diagnosis and clinical precision, patients' and professionals' acceptance and the need for organizational adjustments are also considered limitations of the teleconsultation. The success of the teleconsultation depends on the integration of different organizations and professionals, aiming to maximize its potential and improve service design, encompassing clinical, technical, organizational and context issues. Therefore, it is important to investigate in which contexts, situations and conditions the teleconsultation can be beneficial, safe and effective for patient care, as well as the most appropriate means of communication. 


\section{RESUMO}

\section{PALAVRAS-CHAVE}

- Teleconsulta.

- Telemedicina.

- Consulta Remota.

- Assistência ao paciente.

A teleconsulta médica pode utilizar diferentes tecnologias para mediar a comunicação entre médico e paciente localizados em espaços geográficos diferentes. A implementação dessa ferramenta tem sido incentivada em diversos países, sob a alegação de seu potencial em superar distâncias, oferecendo cuidados em saúde em menor tempo, com redução de custos e da carga de trabalho. A escassez de evidências sobre essas alegações, além do esclarecimento sobre as situações nas quais a teleconsulta pode ser adequada, segura e eficaz, tem gerado debates, intensificados após a publicação da Resolução no 2.227/2018 pelo Conselho Federal de Medicina (CFM), que permitiu a teleconsulta médica, com premissas e recomendações. Este artigo visa analisar as experiências internacionais da teleconsulta médica, incluindo os meios de comunicação e tecnologias empregados, sua utilização, benefícios e limitações, evidenciando e relacionando os pontos polêmicos da resolução publicada pelo CFM. Foi realizada uma revisão integrativa da literatura para identificar essas experiências em quatro bases de dados, de janeiro de 2013 a fevereiro de 2019. Das 1.912 referências encontradas, foram analisadas 42, após a aplicação dos critérios de exclusão e inclusão. A coleta e a análise de dados indicaram que sistemas de telefonia, e-mail, consulta eletrônica, vídeo ou uma combinação deles têm sido utilizados em diversos países para mediar a relação médico-paciente. Sua aplicação vai do diagnóstico ao tratamento, ao monitoramento, ao manejo e à prescrição tanto de condições agudas quanto crônicas. Os principais benefícios incluem menor demanda por consultas presenciais, com possibilidade de gerenciamento da carga de trabalho dos médicos, permitindo uma reorganização dos sistemas. Além disso, a teleconsulta permite superar barreiras de distância, de maneira flexível e conveniente para os pacientes, com a possibilidade de contribuir para a continuidade do cuidado, autonomia do paciente e economia de recursos, nesse último caso, quando se evita o absenteísmo laboral para atendimento médico presencial. Algumas limitações da teleconsulta incluem a incapacidade de realizar o exame físico, e por essa razão ela não é recomendada para a primeira consulta. As dificuldades técnicas e de comunicação para cada meio de comunicação e sua inadequação para determinados grupos de pacientes são outras barreiras importantes. A segurança, tanto dos dados quando da acurácia do diagnóstico e da precisão clínica, a aceitação dos pacientes e profissionais e a necessidade de mudanças organizacionais também são consideradas limitações da teleconsulta. O sucesso da teleconsulta depende da integração de diferentes organizações e profissionais, que deverão, por meio de planejamento cuidadoso, maximizar seu potencial e melhorar o desenho do serviço, englobando questões clínicas, técnicas, organizacionais e do contexto. Portanto, é importante pesquisar em quais situações e agravos a teleconsulta pode ser benéfica, segura e eficaz para o cuidado ao paciente, assim como o meio de comunicação mais apropriado para cada uma delas.

Received on 09/09/19

Accepted on 09/25/19

\section{INTRODUCTION}

Telemedicine is presented as a strategic alternative to decentralization and improving access to medical care, allowing the reduction of costs and travel time for patients ${ }^{1}$. It appeared in the 1950s, but it has had significant advances since the 1990s, with the emergence of the internet and the increasing role of technology in our daily lives ${ }^{2}$.

Telehealth has the same origin and purpose, but it encompasses other areas of health in addition to Medicine. Its development in Brazil was characterized by isolated initiatives in the 1980s and 1990s, but concrete efforts by the Ministry of Health took place as of 2005. Ordinance N. 35 GM/MS, of 2007, established the National Telehealth Program to support Primary Health Care, by providing tele-education, second formative opinion and telediagnosis actions ${ }^{3}$. Medical teleconsultation was not foreseen in the provision of services, since it was not regulated in Brazil.

According to data from 2017, medical teleconsultation is authorized, with some restrictions, across United States. In Europe, 24 of the 28 member countries have specific legislation on the subject and only three prohibit its use. Canada, Australia, Japan and Mexico have already implemented a medical teleconsultation system. In Brazil, teleconsultations are allowed for some areas of health, such as speech therapy, psychology and nursing, under specific conditions or with certain restrictions ${ }^{4}$.

The first specific restriction on medical teleconsultation in Brazil is in the fourth version of the Medical Code of Ethics ${ }^{5}$ of 1965, which forbids doctors to "give consultations, diagnoses or prescriptions through newspapers, radio, television or correspondence [...]". In its sixth version, this restriction became clearer, prohibiting doctors from "prescribing treatment or other procedures without direct examination of the patient, except in cases of urgency or emergency and proven impossibility of performing it, in which case, they must do so immediately, after the impediment ceases"6 (Art. 37).

However, there remains a need for communication between doctor and patient, whether to present test results, clarify doubts or in urgent cases. What was previously done by letter or phone call, started to occur by e-mail and instant messaging apps. This fact led the Federal Council of Medicine (CFM, Conselho Federal de Medicina) to issue an opinion in 2017 approving the use of WhatsApp and similar platforms to send data or consultations between doctors and their patients, as long as they remain private and confidential ${ }^{7}$.

Additionally, regular practices of telehealth initiatives, such as telediagnosis, teleconsulting and tele-education - in secure environments,

REVISTA BRASILEIRA DE EDUCAÇÃO MÉDICA

2 44 (1) : e002; 2020 
with digital security and restricted access - have gained the trust of healthcare professionals and patients. Moreover, there is a growing technological development, especially in large private hospitals, in addition to the expansion of research and successful international experiences in medical teleconsultation.

The new Medical Code of Ethics, published in 2018, adds to the text of article 37 of the previous codes that the docotor is prohibited from consulting, diagnosing or prescribing through any means of mass communication $^{8}$. A regulation for remote medical care mentioned in the first paragraph of this article was published on December 13, 2018. In addition to defining teleconsultation as a "remote medical consultation, mediated by technologies, with doctor and patient located in different geographical spaces"', CFM Resolution N. 2,227/2018 defined other modalities of telemedicine and detailed some assumptions, recommendations and conditions under which they should occur. Its publication was controversial, and this resolution was withdrawn before it came into force, subject to adjustments and new agreements.

Therefore, for clarification and information, a detailed analysis of medical teleconsultation is provided through a literature review of international experiences, considering the different means of communication and technologies employed, their use, benefits and limitations. Additionally, it is important to identify what these publications show about the controversial points of Resolution N. 2,227/2018 regarding the means of communication used, the indications for teleconsultation, data security and the doctor-patient relationship.

\section{METHOD}

This study aimed to systematically collect and compile the results of several publications on medical teleconsultation that used different methodologies, including non-experimental ones ${ }^{10}$. The guiding question was: What are the worldwide medical teleconsultation experiences, considering their use, benefits and limitations for patient care?

\section{Database search strategy}

To search for publications, four databases were selected: Latin American and Caribbean Health Sciences Information System (Lilacs), Scientific Electronic Library Online (Scielo), Scopus and Publisher Medline (PubMed). A search key was created for each database, combining the Boolean operator "AND" with the Medical Subject Headings (MeSH terms) "Telemedicine" and "Remote Consultation" (Table 1). Titles, abstracts and keywords were screened. The choice of such a broad search strategy was due to the inconsistency of the terms adopted on the subject of teleconsultation, found in previous studies.

\section{Study selection}

The inclusion criteria were established taking into account the research question, maintaining for the analysis the publications that addressed the use, benefits and or limitations of medical teleconsultation for patient care, written in English, Portuguese or Spanish. Given the emerging characteristic and scarcity of studies on the subject, it was decided to include original and opinion articles, literature reviews, editorials, letters and reports of experiences published in scientific journals. Also included were articles addressing the use of teleconsultation to assist specific conditions.
Studies that did not address the guiding question were excluded, including those that addressed specific areas of telediagnosis, such as teledermatology, telepathology and teleophthalmology, as well as continuous monitoring by telemonitoring actions involving collection sensors and tele-education actions. Moreover, studies that addressed the electronic referencing system, virtual reality devices, support for emergencies or cases in which the interaction took place with another health professional, other than the doctor, were excluded.

\section{Data analysis}

An instrument containing the information necessary to answer the research question was adapted from Ursi and Gavão $(2006)^{11}$ to guide data collection, allowing the content organization and the grouping into categories, for later presentation of the descriptive analysis.

The categories collected and analyzed in relation to publication were: author, year, title, journal, country and language of publication, study period and approach, research question, objective, data collection method and analysis, sample size and/or research participants, main results, conclusions, weaknesses and strengths of the publication.

Regarding teleconsultation, the categories collected and analyzed, when present, were: moment of interaction (synchronous or asynchronous), character (additive, substitutive or alternative), the means of communication or technology adopted, the employed terminology, the medical specialty, the purpose of the teleconsultation, the nature of the service (public or private), use restrictions, payment method and its main benefits and limitations.

\section{RESULTS}

The search in the databases encompassing journals from January 2013 to February 2019 resulted in 1,912 references. Of these, 754

\begin{tabular}{|c|c|c|}
\hline \multicolumn{3}{|c|}{$\begin{array}{r}\text { Table } 1 \\
\text { Search keys and results in each data }\end{array}$} \\
\hline DATABASE & SEARCH KEYS & TOTAL \\
\hline LILACS & $\begin{array}{l}\text { (tw:(“Consulta Remota" OR teleconsulta OR } \\
\text { teleconsultas OR "remote consultation" OR } \\
\text { "remote consultations" OR “teleconsultation" OR } \\
\text { "teleconsultations")) AND (tw:(“telemedicina" OR } \\
\text { "telemedicine" OR "telehealth" OR "eHealth")) } \\
\text { AND (instance:"regional”) AND ( db:(“LILACS")) }\end{array}$ & 59 \\
\hline SCIELO & $\begin{array}{l}\text { (“Consulta Remota" OR teleconsulta OR } \\
\text { teleconsultas OR "remote consultation" OR } \\
\text { "remote consultations" OR teleconsultation } \\
\text { OR teleconsultations) AND (telemedicina OR } \\
\text { telemedicine OR telehealth OR eHealth) }\end{array}$ & 21 \\
\hline PubMed & $\begin{array}{l}\text { (("remote consultation" [MeSH Terms] OR "remote } \\
\text { consultation" OR "remote consultations")) AND } \\
\text { (("telemedicine"[MeSH Terms] OR "telemedicine" } \\
\text { OR "telehealth" OR “eHealth")) }\end{array}$ & 1,206 \\
\hline Scopus & $\begin{array}{c}\text { ("remote consultation" OR "remote consultations") } \\
\text { AND ("telemedicine" OR "telehealth" OR } \\
\text { "eHealth") }\end{array}$ & 626 \\
\hline & TOTAL & 1,912 \\
\hline
\end{tabular}

REVISTA BRASILEIRA DE EDUCAÇ̄̃̃ MÉDICA

3 $44(1):$ e002; 2020 
duplicates were excluded; 662 by title screening; 331 by title and abstract screening; 31 due to unavailability or the fact that it was written in a language different from those selected. The number of publications read in full was 134 and 102 were excluded according to the already described criteria. Subsequently, 10 publications were included manually based on the reference lists and, in total, 42 publications were analyzed (Figure 1). The software Endnote ${ }^{T M}$ Basic was used to manage the references.
Characteristics of the analyzed publications

Chart 1 shows an overview of the 42 selected publications. The highest concentration (15) occurred in the last two years and the country with the largest number of publications was England (15), followed by the United States (10). Brazil had one publication in the analyzed period. Regarding journals, the British Journal of General Practice and the British Medical Journal (BMJ) had the largest number of publications.

\section{Figure 1}

Flowchart of the integrative review on medical teleconsultation experiences, its use, benefits and limitations.

References identified in the

database search

$(\mathrm{n}=1.912)$

Remaining references after removing duplicates $(n=1.158)$

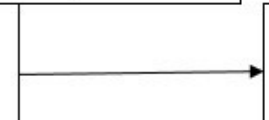

Publications excluded by title screening $(n=662)$

Publications unavailable or written in another language $(n=31)$

Publications excluded according to the criteria $(n=102)$

Manual inclusion $(n=10)$ 
Chart 1

Summary of the main results of the integrative review on the experiences of medical teleconsultation, carried out in February 2019.

\begin{tabular}{|c|c|c|c|c|c|c|}
\hline AUTHORS / YEAR & COUNTRY & JOURNAL & STUDY DESIGN & $\begin{array}{c}\text { MEANS OF } \\
\text { COMMUNICATION }\end{array}$ & $\begin{array}{l}\text { TYPE OF } \\
\text { SERVICE }\end{array}$ & $\begin{array}{c}\text { ADOPTED } \\
\text { TERMINOLOGY }\end{array}$ \\
\hline Agnihotri e Koralnik (2015) ${ }^{13}$ & USA & Annals of Neurology & Trial & Telephone, e-mail, video & Private & Cyberconsultation \\
\hline Albert, Agimi e Martich $(2015)^{14}$ & USA & $\begin{array}{c}\text { The American Journal } \\
\text { of Managed Care } \\
\text { (AJMC) }\end{array}$ & Quantitative study & $\begin{array}{c}\text { Sistema de consulta } \\
\text { eletrônica }\end{array}$ & Private & eConsultation \\
\hline $\begin{array}{l}\text { Atherton, Brant, Ziebland, Bikker, } \\
\text { Campbell, Gibson et al. } \\
(2018)^{15}\end{array}$ & England & $\begin{array}{l}\text { British Journal of } \\
\text { General Practice }\end{array}$ & Quantitative study & $\begin{array}{l}\text { Telephone, e-mail, video, } \\
\text { sistema de consulta } \\
\text { eletrônica }\end{array}$ & Public & $\begin{array}{l}\text { Alternatives to face-to- } \\
\text { face consultations }\end{array}$ \\
\hline $\begin{array}{l}\text { Atherton, Pappas, Heneghan e } \\
\text { Murray }(2013)^{16}\end{array}$ & England & $\begin{array}{l}\text { British Journal of } \\
\text { General Practice }\end{array}$ & Quantitative study & E-mail & Public & Consultation by e-mail \\
\hline Atherton e Ziebland $(2016)^{17}$ & England & Digital Health & Trial & Telephone, e-mail, video & Public & $\begin{array}{l}\text { Alternatives to face-to- } \\
\text { face consultations }\end{array}$ \\
\hline $\begin{array}{l}\text { Ballesteros, Granja, Carrasco, Benito, } \\
\text { Álvarez, Ramnón et al. }(2018)^{18}\end{array}$ & Spain & $\begin{array}{l}\text { Medicina de Família } \\
\text { SEMERGEN }\end{array}$ & Quantitative study & Telephone, e-mail & Public & Remote consultation \\
\hline $\begin{array}{l}\text { Banks, Farr, Salisbury, Bernard, } \\
\text { Northstone, Edwards et al. }(2018)^{12}\end{array}$ & England & $\begin{array}{l}\text { British Journal of } \\
\text { General Practice }\end{array}$ & Quantitative study & $\begin{array}{l}\text { Electronic consultation } \\
\text { system }\end{array}$ & Public & $\begin{array}{c}\text { Remote Consultation / } \\
\text { Electronic consultation } \\
\text { system }\end{array}$ \\
\hline
\end{tabular}

Bertelsen e Stub Petersen (2015) $)^{19} \quad$ Denmark Medinfo Puantitative study Telephone, e-mail healthcare

\begin{tabular}{|c|c|c|c|c|c|c|}
\hline $\begin{array}{l}\text { Bishop, Press, Mendelsohn e } \\
\text { Casalino }(2013)^{20}\end{array}$ & USA & $\begin{array}{l}\text { Health and Information } \\
\text { Technology }\end{array}$ & Quantitative study & E-mail & $\begin{array}{l}\text { Public / } \\
\text { private }\end{array}$ & $\begin{array}{c}\text { Electronic consultation } \\
\text { program }\end{array}$ \\
\hline
\end{tabular}

Brant, Atherton, Ziebland,

McKinstry, Campbell e Salisbury $(2016)^{21}$

England

British Journal of

Mixed Methods - Telephone, e-mail, video

Public

Alternatives to face-to-

Cowie, Calveley, Bowers e Bowers $(2018)^{22}$

Scotland International Journal

of Environmental

Research and Public

Mixed Methods Electronic consultation Public

eConsultation /

Health

system

Electronic consultation system

\begin{tabular}{|c|c|c|c|c|c|c|}
\hline Drago, Winding e Antypa (2016) ${ }^{23}$ & Denmark & European Psychiatry & Meta-analysis & Video & $\begin{array}{l}\text { Public / } \\
\text { private }\end{array}$ & Videoconference \\
\hline $\begin{array}{c}\text { Edwards, Marques, } \\
\text { Hollingworth, Horwood, Farr, } \\
\text { Bernandr et al. }(2017)^{24}\end{array}$ & England & BMJ Open & Quantitative study & $\begin{array}{l}\text { Electronic consultation } \\
\text { system }\end{array}$ & Public & $\begin{array}{l}\text { Remote consultation/ } \\
\text { Electronic consultation } \\
\text { system }\end{array}$ \\
\hline $\begin{array}{l}\text { Fatehi, Armfield, Dimitrijevic e } \\
\text { Gray }(2014)^{25}\end{array}$ & Australia & $\begin{array}{c}\text { Journal of Telemedicine } \\
\text { and Telecare }\end{array}$ & Literature Review & Video & $\begin{array}{l}\text { Public / } \\
\text { private }\end{array}$ & Videoconference \\
\hline Ferreira $(2018)^{26}$ & Portugal & Medicina Interna & Opinion Article & Video & $\mathrm{NM}^{*}$ & Teleconsultation \\
\hline $\begin{array}{l}\text { Flodgren, Rachas, Farmer, Inzitari } \\
\text { e Shepperd }(2015)^{27}\end{array}$ & England & $\begin{array}{l}\text { Cochrane Database of } \\
\text { Systematic Reviews }\end{array}$ & Systematic Review & $\begin{array}{l}\text { E-mail, video, Electronic } \\
\text { consultation system }\end{array}$ & $\begin{array}{l}\text { Public / } \\
\text { private }\end{array}$ & Interactive Telemedicine \\
\hline Frade e Rodrigues $(2013)^{28}$ & Portugal & Medinfo & Literature Review & Video & $\mathrm{NM}^{*}$ & Teleconsultation \\
\hline $\begin{array}{l}\text { Greenhalgh, Shaw, Wherton, } \\
\text { Vijayaraghavan, Morris, } \\
\text { Bhattacharya et al. }(2018)^{29}\end{array}$ & England & $\begin{array}{l}\text { Journal of Medical } \\
\text { Internet Research }\end{array}$ & Mixed methods & Video & Public & Videoconsultation \\
\hline $\begin{array}{l}\text { Hickey, Gomez, Meller, Schneider, } \\
\text { Cheney, Nejad et al. }(2017)^{30}\end{array}$ & USA & Burns & Quantitative study & Video & Private & $\begin{array}{l}\text { Interactive telehealth visit } \\
\text { at home }\end{array}$ \\
\hline $\begin{array}{l}\text { Hoek, Schers, Bronkhorst, Vissers } \\
\text { e Hasselaar }(2017)^{31}\end{array}$ & $\begin{array}{l}\text { The } \\
\text { Netherlands }\end{array}$ & BMC Medicine & Quantitative study & Video & $\begin{array}{l}\text { Public / } \\
\text { private }\end{array}$ & Teleconsultation \\
\hline Iacobucci G. $(2017)^{32}$ & England & The BMJ & Opinion Article & Video & Public & Online consultation \\
\hline Jury e Kornberg $(2016)^{33}$ & Australia & $\begin{array}{c}\text { Journal of Telemedicine } \\
\text { and Telecare }\end{array}$ & Quantitative study & Video & $\mathrm{NM}^{*}$ & $\begin{array}{l}\text { Videoconference through } \\
\text { web telehealth }\end{array}$ \\
\hline
\end{tabular}




\begin{tabular}{|c|c|c|c|c|c|c|}
\hline & & & $\begin{array}{c}\text { Chart } 1 \\
\text { Continuation }\end{array}$ & & & \\
\hline AUTHORS / YEAR & COUNTRY & JOURNAL & STUDY DESIGN & $\begin{array}{c}\text { MEANS OF } \\
\text { COMMUNICATION }\end{array}$ & $\begin{array}{l}\text { TYPE OF } \\
\text { SERVICE }\end{array}$ & $\begin{array}{l}\text { ADOPTED } \\
\text { TERMINOLOGY }\end{array}$ \\
\hline Kew e Cates $(2016)^{34}$ & England & Cochrane & Systematic Review & Telephone, video & $\begin{array}{l}\text { Public / } \\
\text { private }\end{array}$ & Remote checkup \\
\hline $\begin{array}{l}\text { Ladino, Wiley, Schulman, } \\
\text { Sabucedo, Garcia, Cardona et al. } \\
(2016)^{35}\end{array}$ & USA & $\begin{array}{l}\text { Telemedicine and } \\
\text { e-health }\end{array}$ & Quantitative study & Video & Public & Videoconference \\
\hline $\begin{array}{l}\text { LeRouge, Garfield e Hevner } \\
\qquad(2015)^{36}\end{array}$ & USA & $\begin{array}{c}\text { Patient Preference and } \\
\text { Adherence }\end{array}$ & Mixed Methods & Video & Public & Medical Videoconference \\
\hline $\begin{array}{c}\text { Lipana, Bindal, Nettiksimmons e } \\
\text { Shaikh }(2013)^{37}\end{array}$ & USA & $\begin{array}{l}\text { Telemedicine and } \\
\text { e-health }\end{array}$ & Quantitative study & Video & Private & Telemedicine Care \\
\hline Liston $(2013)^{38}$ & England & $\begin{array}{l}\text { British Journal of } \\
\text { General Practice }\end{array}$ & Opinion Article & Telephone & Public & $\begin{array}{l}\text { Initial approach by } \\
\text { telephone }\end{array}$ \\
\hline $\begin{array}{l}\text { Liu, Saxon, McNair, Sanagorski e } \\
\text { Rasouli }(2016)^{39}\end{array}$ & USA & $\begin{array}{l}\text { Journal of Diabetes } \\
\text { Science and Technology }\end{array}$ & Quantitative study & Video & Public & Telehealth Consultation \\
\hline McCartney $(2017)^{40}$ & England & BMJ & Opinion Article & Video & Public & Virtual Consultation \\
\hline McGrail, Ahuja e Leaver $(2017)^{41}$ & Canada & $\begin{array}{l}\text { Journal of Medical } \\
\text { Internet Research }\end{array}$ & Mixed Methods & Video & Public & Virtual Visits \\
\hline $\begin{array}{l}\text { McLean, Sheikh, Cresswell, } \\
\text { Nurmatov, Mukherjee, Hemmi } \\
\text { et al. }(2013)^{42}\end{array}$ & Scotland & Plos One & Meta-analysis & Telephone, e-mail, video & $\begin{array}{l}\text { Public / } \\
\text { private }\end{array}$ & Telehealth Care \\
\hline $\begin{array}{l}\text { Moth, Huibers, Christensen e } \\
\text { Vedsted }(2014)^{43}\end{array}$ & Denmark & BMC Family Practice & Quantitative study & Telephone & Public & Telephone Consultation \\
\hline $\begin{array}{l}\text { Newbould, Abel, Ball, Corbett, } \\
\text { Elliott, Exley et al. }(2017)^{44}\end{array}$ & England & $\mathrm{BMJ}$ & Quantitative study & Telephone & Public & $\begin{array}{l}\text { Initial approach by } \\
\text { telephone }\end{array}$ \\
\hline $\begin{array}{l}\text { Ohta, Ohira, Uehara, Keira, } \\
\text { Noda, Hirukawa et al. }(2017)^{45}\end{array}$ & Japan & $\begin{array}{l}\text { Telemedicine and } \\
\text { E-health }\end{array}$ & Quantitative study & Video & $\mathrm{NM}^{*}$ & $\begin{array}{l}\text { Synchronized visits by } \\
\text { video }\end{array}$ \\
\hline Plener, Hayward e Saibil $(2014)^{46}$ & Canada & $\begin{array}{c}\text { Canadian Journal of } \\
\text { Gastroenterology and } \\
\text { Hepatology }\end{array}$ & Literature Review & Email & Public & Email Communication \\
\hline $\begin{array}{l}\text { Poulsen, Millen, Lakshman, } \\
\text { Buttner e Roberts }(2015)^{47}\end{array}$ & Australia & $\begin{array}{c}\text { International Journal of } \\
\text { Rheumatic Diseases }\end{array}$ & Quantitative study & Video & $\mathrm{NM}^{*}$ & $\begin{array}{l}\text { Videoconsultation/ } \\
\text { Videoconference }\end{array}$ \\
\hline Rosenzweig e Baum (2013) ${ }^{48}$ & USA & $\begin{array}{c}\text { Journal of Medical } \\
\text { Practice Management }\end{array}$ & Trial & Video, e-mail, message & Privado & Virtual Consultations \\
\hline $\begin{array}{l}\text { Sabesan, Allen, Loh, Caldwell, } \\
\text { Mozer, Komesarof et al. }(2013)^{49}\end{array}$ & Australia & $\begin{array}{l}\text { Internal Medicine } \\
\text { Journal }\end{array}$ & Experience Report & Video & Public & Videoconference \\
\hline $\begin{array}{c}\text { Schmitz, Gonçalves, Umpierre, } \\
\text { Siqueira, D’Ávila, Bastos et al. (2017) }\end{array}$ & Brazil & $\begin{array}{l}\text { Revista Brasileira de } \\
\text { Medicina da Família e } \\
\text { Comunidade }\end{array}$ & Literature Review & Telephone, e-mail, video & $\begin{array}{l}\text { Public / } \\
\text { private }\end{array}$ & Teleconsultation \\
\hline Torjesen I. $(2016)^{50}$ & England & $\mathrm{BMJ}$ & Opinion Article & Video & Public & Remote Consultation \\
\hline $\begin{array}{l}\text { Welch, Harvey, O'Connell e } \\
\text { McElligott }(2017)^{51}\end{array}$ & USA & $\begin{array}{c}\text { BMC Health Services } \\
\text { Research }\end{array}$ & Quantitative study & Video & $\begin{array}{l}\text { Public / } \\
\text { private }\end{array}$ & $\begin{array}{l}\text { Telemedicine services } \\
\text { with a direct consumer } \\
\text { approach }\end{array}$ \\
\hline Young $(2016)^{52}$ & England & $\begin{array}{l}\text { British Journal of } \\
\text { General Practice }\end{array}$ & Editorial & $\begin{array}{l}\text { E-mail, video, electronic } \\
\text { consultation system }\end{array}$ & Public & Videoconsultation \\
\hline
\end{tabular}

${ }^{\star} \mathrm{NM}=$ not mentioned.

Different means of communication were analyzed, with video being the most frequently used one (20). The telephone (3) appeared as a screening mechanism, but also for basic advice or for resolving administrative issues, with the last two being also carried out by e-mail (4). The electronic consultation system (4), also found as an alternative to teleconsultation, consists of an online platform with symptom checker, pharmaceutical assistance locator and the possibility of having access to administrative services, such as showing test results and requesting a prescription for continuous-use medication ${ }^{12}$. Moreover, publications were found that analyzed a combination of means of communication, with the combination 
of telephone, e-mail and video being the most frequent one (5).

The terminologies used for the teleconsultation varied, even being different for the same means of communication. With video being the most frequently used strategy, it showed the highest number of nomenclatures.

\section{Descriptive Analysis}

As for the use of medical consultation, it can be additive (when it adds moments of interaction between doctor and patient, in addition to face-toface consultations), alternative (when teleconsultation replaces the face-to-face consultation) or partially substitutive (when some face-to-face consultations are replaced by teleconsultations during treatment or follow-up $)^{27}$.

Using this classification, the articles reported that the telephone can be used as an additive, alternative or partially substitutive type of consultation ${ }^{38,43-44}$. E-mail, on the other hand, has been used in an additive ${ }^{16}$ or partially substitutive ${ }^{16,20}$ consultation, especially for scheduling appointments, renewing prescriptions, solving doubts and to present test results ${ }^{19}$.

The electronic consultation system has been used for administrative services, managing specific conditions, solving doubts and providing medical recommendations ${ }^{12,22,24}$. The video, on the other hand, has been used to intermediate the doctor-patient relationship as an additive, alternative or partially substitutive consultation for acute, subacute and chronic care. However, its use has mostly (91\%) a combination of purposes: management, diagnosis, counseling and monitoring ${ }^{25}$. Studies indicate that its main use has been the management of chronic diseases ${ }^{25-26}$.
The combination of the aforementioned means of communication has been used as an additive and partially substitutive consultation ${ }^{19}$, especially for the return of patients ${ }^{21,48}$. Among its main uses are administrative issues, solving doubts about medications and to present test results, as well as solving most of the follow-up of acute and chronic problems ${ }^{18}$.

A summary of each means of communication used was grouped in Chart 2, considering its benefits and limitations.

\section{DISCUSSION}

Technology has been transforming everyday relationships. In some countries, alternative forms of communication between patients and doctors are a reality or a claim due to the growing demand for health care, despite the skepticism of health professionals and their advice ${ }^{21}$. Although there are many concerns about the use of medical teleconsultation, the world scenario shows investments and growing representativeness in research on its use and adequacy for the improvement of care, as well as the analysis of its limitations and benefits.

In the British healthcare system, the National Health Service (NHS), this recent debate is justified by the growing demand for primary care, to overcome distances, respond to patient expectations in a short time, improve efficiency and manage the unmet demands ${ }^{15}$. The British Department of Health Policy launched in 2012 declared that all patients should be able to communicate electronically with their healthcare team by $2025^{21}$.

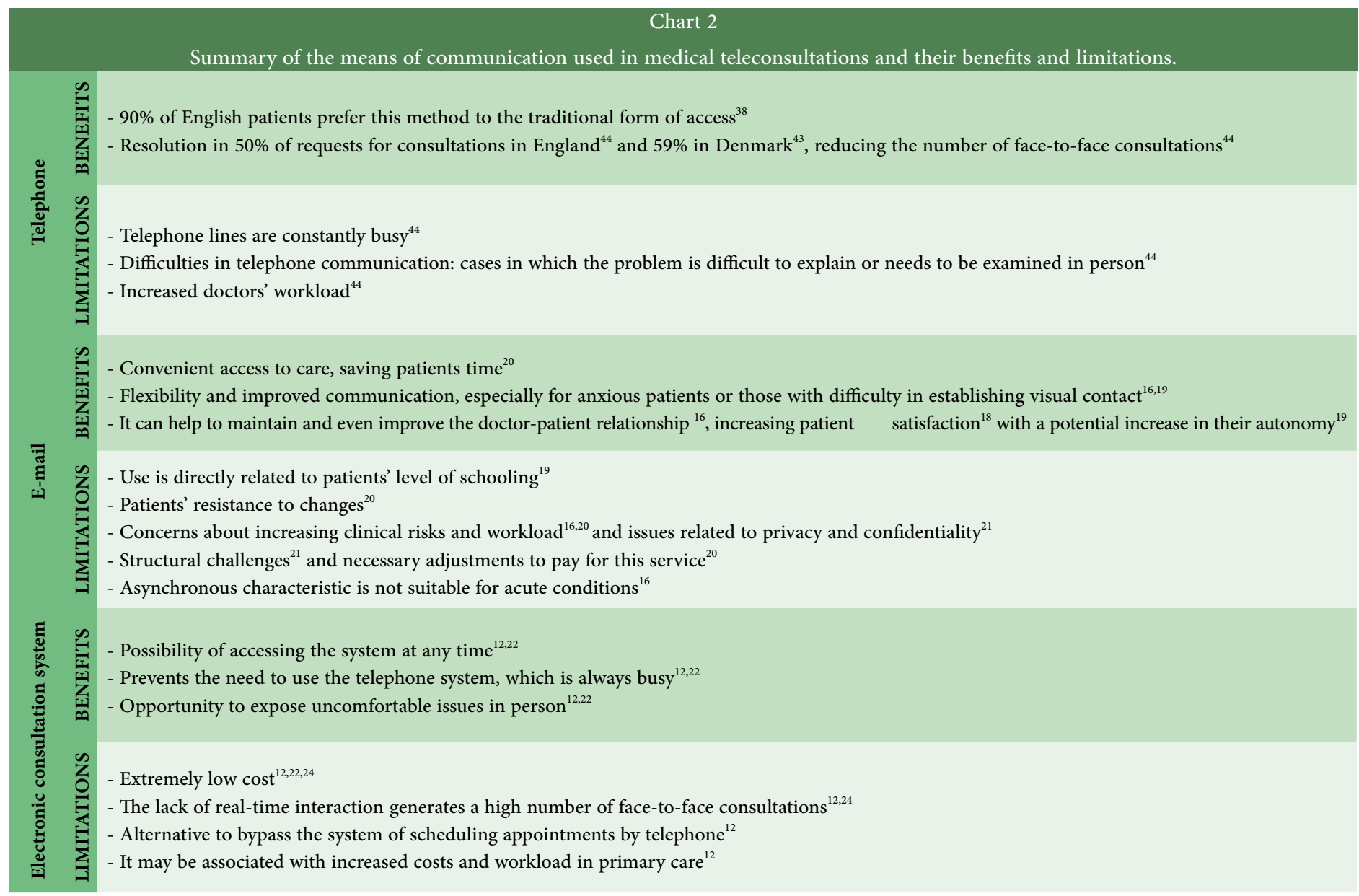




\begin{tabular}{|c|c|c|}
\hline & & $\begin{array}{c}\text { Chart } 2 \\
\text { Continuation }\end{array}$ \\
\hline & 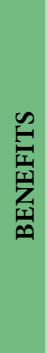 & $\begin{array}{l}\text { - The diagnosis can be as accurate as face-to-face }{ }^{45} \\
\text { - Way to overcome distances and provide care without displacing the patient } t^{21,26,28,49} \\
\text { - Resource that meets the patients' requests for additional visits and strengthens supervised self-care }{ }^{29} \text {, with an effective monitoring of adherence to drug } \\
\text { therapy and change of habits, minimizing the risks of treatment interruption }{ }^{26} \\
\text { - It can promote the reorganization of health systems to a patient-centered approach, with the possibility of improving primary care provision }{ }^{31} \\
\text { - Resource savings } \\
\text { - Useful for some patients }{ }^{26,32} \text { and their selection depends on the doctor's experience, the patient's circumstances and preferences, the capacity of the } \\
\text { service and the complexity of the case }{ }^{49} \\
\text { - Adapts to current time limitations for health care }{ }^{41}\end{array}$ \\
\hline & 恣 & $\begin{array}{l}\text { - Inability to perform the patient's physical examination }{ }^{25,26,28} \\
\text { - Patients are less willing to use it with an unknown doctor }{ }^{51} \text { and the distance can have a negative impact on the doctor-patient relationship }{ }^{15} \\
\text { - Patient eligibility }{ }^{29,50} \text { and decreased access for vulnerable patients, especially the elderly }{ }^{15,41} \text { or those with difficulties in using technological resources } \\
\text { - Resistance by professionals }{ }^{29} \text { and patients }{ }^{15,29} \text { or, also, difficulty using it }{ }^{28,29} \\
\text { - Technical challenges can hinder the doctors' work } \\
\text { - Concerns about data security }{ }^{26,45,50} \text { and clinical conduct accuracy }{ }^{26,45,50} \\
\text { - Resource savings evidence is not robust to justify its implementation }{ }^{42} \\
\text { - Increased workload }{ }^{32}, \text { structural changes }^{15} \text { and organizational difficulties to establish new routines and overcome regulatory or political issues }\end{array}$ \\
\hline تֶ & 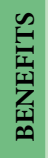 & $\begin{array}{l}\text { - Improves the continuity of patient care }{ }^{18,49} \text {, when used as additive or partially substitutive consultation, helping to confirm diagnoses or identifying the } \\
\text { need for another face-to-face consultation }{ }^{21} \text {, enabling workload management }{ }^{18,21} \\
\text { - It can improve primary care provision and lead to a more efficient use of the professionals' time }{ }^{21} \text {, increasing the time devoted to patient care }{ }^{18} \\
\text { - Advantage for patients with mobility or communication difficulties }\end{array}$ \\
\hline 暜 & 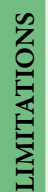 & $\begin{array}{l}\text { - Because it improves access, the workload of doctors and health units increases }{ }^{21} \\
\text { - Increased clinical risk and concerns about privacy and confidentiality } \\
\text { - Technological challenges: connection speed and stability, software } \\
\text { - Patient eligibility: disadvantage for certain groups, such as the elderly, for instance }{ }^{21}\end{array}$ \\
\hline
\end{tabular}

However, some doctors stress the importance of resisting pressure until there is consistent evidence that teleconsultation can save resources and be beneficial. Its implementation should aim at the quality of care in a non-harmful way, favoring the patients' autonomy, while assuring security in data sending and storage ${ }^{32}$. There is a large number of short-term feasibility studies with small samples, which implies limited conclusions. Additionally, the lack of consensus on the terminology is a critical factor for the development of researches ${ }^{42}$.

Overall, the limitations can be placed in two large groups: in the United States $^{20,48}$, Australia ${ }^{33}$, and Japan ${ }^{45}$ the raised issues are under the logic of the market, including productivity and billing, or technical-administrative issues, in the effort to integrate the teleconsultations into the routine of business as usual, with rare exceptions ${ }^{51}$. In the United Kingdom ${ }^{15-17,21,29,32,40}$, Denmark $^{19,43}$ and Canada ${ }^{41}$ the main concerns refers to equitable access to this innovative service, security - both clinical and data-related - and care with the teleconsultation implementation, more aligned with the principles of universal health systems, currently in place in these countries.

In the Brazilian context, after 50 years of prohibitions on the use of technologies to mediate the doctor-patient relationship, some flexibility commenced, until the CFM Resolution N. 2,227/2018 started to authorize medical teleassistance in the national territory, including principles, recommendations and conditions for its performance ${ }^{9}$. This resolution was subsequently revoked, given the intense debate and raised concerns, especially by doctors and their class associations. It is believed that the international literature on medical teleconsultation can help in this debate and the discussion that follows highlights the controversial issues of the CFM resolution in relation to what was found in this review.

\section{Means of communication}

The Resolution N. 2,227/2018 does not mention which means of communication can be used for medical teleconsultation. It simply states that "medical teleassistance, in real-time online (synchronous) or offline (asynchronous), through multimedia in technology, is allowed inside the national territory"

In the United Kingdom, in an attempt to guarantee access to primary health care, most public health units adopt as a standard procedure a telephone call made by a doctor to the patient who requests an appointment ${ }^{38,43,44}$. This screening mechanism is effective in $50 \%$ of requests for consultations in England ${ }^{44}$ and 59\% in Denmark ${ }^{43}$. However, there is no evidence that this approach would reduce costs ${ }^{13,44}$ or the use of secondary care ${ }^{44}$. Both problem-solving experiences occur in universal systems, but this mechanism does not reduce the need for doctors; additionally, studies have indicated an increase in their workload ${ }^{44}$, which can be justified by meeting a repressed demand. However, this screening has the potential to support the referral, either for the essential face-toface consultation or for other levels of care, when appropriate.

In Denmark, the number of telephone consultations decreased by $20 \%$ and consultations by e-mail increase five-fold between 2007 and 2013. Still, telephone calls are four times more representative in the communication of patients with primary care doctors ${ }^{19}$ - despite the difficulty in explaining the problem without eye contact ${ }^{44}$ and the claims that telephone consultations are more appropriate for simple problems, case follow-up and native patients, given the language difficulties that foreign patients might experience ${ }^{15}$. Another important fact is that one in five telephone calls results in a medical prescription ${ }^{43,44}$. 
As for the use of e-mail, 20 to $25 \%$ of doctors in the United States and Europe affirm they use it to communicate with their patients ${ }^{16}$. Both, patients and doctors, have doubts about the situations in which this means of communication can be adequate and efficient, while guaranteeing data security ${ }^{16}$. Another raised concern refers to the additional workload ${ }^{15,16,20}$ and how to organize the payment for these electronic communications ${ }^{20}$. Currently, North American public health programs (Medcare and Medcaid) do not reimburse communications by e-mail, unlike some private health care systems that are considering different forms of incentives, with monthly reimbursement or payment-per-patient models. On the other hand, some managers claim that they will be paying for something that is already done spontaneously by doctors ${ }^{20}$.

Studies carried out in the United Kingdom have shown that the electronic consultation system in primary care does not effectively meet the patients' need for medical consultations, thus not justifying its funding ${ }^{12,24}$. Although its structure makes it possible to obtain the necessary information for clinical conduct, considered the main advantage in relation to e-mail ${ }^{12}$, the initial submission may result in an appointment for a face-to-face consultation or problem solution by the administrative body itself. The percentage of the need to schedule a face-to-face consultation is high due to the lack of real-time interaction ${ }^{12}$, being $38.1 \%$ in England $^{24}$ and approximately $27 \%$ in Scotland ${ }^{22}$. This means of communication has been considered a way to bypass the system of making appointments over the telephone ${ }^{12}$.

Moreover, international experience has shown that the asynchronous characteristic, such as that of e-mail or the electronic consultation system, is not adequate for acute condition ${ }^{16}$. It is claimed that the use of video devices, which allows a synchronous interaction, can improve access to care for populations living in remote areas, as well as meeting the growing demand from patients with limited motor skills ${ }^{21}$, in addition to adapting better to current time constraints $^{41}$, despite the lack of evidence to support these allegations ${ }^{42}$.

\section{Teleconsultation indications}

The explanatory reasons contained in CFM Resolution N. 2,227 mentions that telemedicine is a natural evolution of health care and that its capacity to improve health care quality, equity and accessibility is undeniable 9 . However, the Resolution does not clarify in which situations teleconsultation is appropriate, mentioning only in its explanatory statement that "it should not be expected that it will become a cure for all health care problems".

Regarding equity and accessibility, the literature states that teleconsultation is not adequate for all patients or for all situations, which can decrease the access of the most vulnerable individuals, with difficulties to use technology ${ }^{15,21,29,32}$ as the elderly ${ }^{15,41}$ or children ${ }^{45}$.

Research on the topic is still deficient regarding the representation of particular strata of the population, such as patients with comorbidities, cognitive impairment, disabilities or social problems ${ }^{42}$. It is known that young patients and doctors are more likely to use video teleconsultation ${ }^{41}$. The electronic consultation system, on the other hand, may be less appropriate for people with learning difficulties, dementia, complex needs and certain health conditions, such as chemical dependency, terminal illnesses, frail women or the elderly ${ }^{40}$. The use of e-mail is directly related to the patients' level of schooling $^{19}$ and the telephone is more appropriate for native patients ${ }^{15}$.

Several studies were found addressing the management of chronic diseases and specific acute situations. As for the situations in which medical teleconsultation can be indicated, this review identified 11 studies that addressed specific conditions, 7 of which used video teleconsultation and the other three used the electronic consultation system or a combination of video and telephone or even video, phone and email.

Studies that compared medical teleconsultation by video with faceto-face consultations identified equivalent results regarding glycemic control of individuals with diabetes ${ }^{39}$, as well as in exacerbations, disease control and quality of life of patients with asthma ${ }^{34}$ and in the treatment of childhood obesity ${ }^{37}$. High rates of satisfaction were also identified among patients treated for rheumatological diseases ${ }^{47}$ and better experience of care and health outcomes in nephrology care ${ }^{35}$.

Video teleconsultation also shows to be as a safe and viable modality for outpatient care of $h$ burn injuries ${ }^{30}$ and in the assessment and treatment of common mental disorders. However, in the latter case, the authors warned about being careful in generalizing the results ${ }^{23}$. Other studies also indicate the need for future studies ${ }^{30,34,47}$, with a promising potential ${ }^{37}$.

On the other hand, video teleconsultation as an additive to palliative care, compared to usual palliative care, led to a greater burden of symptoms reported by patients in home care with advanced cancer, despite the high degree of satisfaction with the service. A possible explanation is that the model is oriented towards care offer, regardless of the patients' needs, providing excessive attention to symptoms and suffering ${ }^{31}$.

The incorporation of e-mail in the self-management of chronic diseases, such as inflammatory bowel disease, has the potential to improve care and clinical safety, as long as there are clear limitations and situations in which this means of communication is appropriate ${ }^{46}$. Teleconsultation, using a combination of telephone, e-mail and video in the treatment of rare diseases, allows contact with a greater number of patients with the same conditions, overcoming geographical barriers and making it possible to expand doctors' knowledge and scope of action ${ }^{13}$. Finally, a large number of mental disorders not foreseen in an electronic consultation system were identified under the term "others". Despite the need to develop online tools for the diagnosis and treatment of these disorders, patients must be aware of the risks that this system presents, and one questions whether decisions made based on algorithms would be appropriate, given the nature of these conditions and the therapeutic importance of the relationship with the doctor ${ }^{14}$.

In addition to the studies presented herein, Greenhalgh et al. ${ }^{29}$ mention some randomized clinical trials that demonstrate the acceptability, security and efficacy of teleconsultation, with the potential to reduce individual costs when this factor is evaluated, since it is appropriate for patients in the following conditions: diabetes, chronic kidney disease, chronic obstructive pulmonary disease, mental health, chronic pain, orthopedic surgery, plastic surgery, prostate cancer, preterm birth support and patients in nursing homes.

It seems necessary to continue identifying for which situations and conditions it is indicated, as well as the appropriate means of communication for each of them, considering their synchronicity or not.

\section{Data security}

The analysis of CFM Resolution N. 2,227/2018 ${ }^{9}$ together with CFM Opinion N. 14/2017, which allows the use of WhatsApp and similar apps for communication between doctors and patients ${ }^{7}$, gives rise to the

REVISTA BRASILEIRA DE EDUCAÇÃO MÉDICA

$94(1): \mathrm{e} 002 ; 2020$ 
understanding that it is permitted to conduct medical teleconsultation through that means. It is important to make a point regarding data security, expressed in the third article of the Resolution, in relation to the need for infrastructure to ensure the appropriate, secure and unified digital record in telemedicine services, meeting the requirements of the Security Guarantee Level 2 (NGS2) and the ICP-Baszil standard'.

Regarding the findings in the literature, two US studies mention that for a teleconsultation to occur, both patient and doctor must have access to a HIPAA-compliant system, that is, certified according to the Health Insurance Portability and Accountability Act (HIPAA) ${ }^{30,48}$. Approved in 1996, the HIPPA - Health Insurance Portability and Accountability Law - establishes a set of rules to protect health information. This accreditation is similar to the certification process carried out by the Brazilian Society of Medical Informatics for electronic health record systems, except that, in the US case, it covers also communication systems between doctor and patient by video or text messages. Another British study points out that patient privacy and confidentiality are important points not commonly addressed ${ }^{17}$.

Despite being an application protected by end-to-end encryption, which some studies found in the review by Flodgren et al. consider a guarantee of confidentiality ${ }^{27}$, the images, audios and documents sent via WhatsApp are saved on the mobile device, which can be easily stolen or intercepted. Given the lack of specific regulations, it is up to the doctor to decide in which situations this means is suitable for communicating with the patient, in addition to the fact, as established in the Resolution, that doctors are responsible for keeping the information. This medical responsibility is not reported in the analyzed literature, but it is known that technical challenges can harm the work of doctors ${ }^{29,33}$, who must focus on patient care ${ }^{36}$.

Regarding the patient's unified Electronic Health Record, it is worth reflecting on how it will be possible to interoperate information in the private system, which acts in a fragmented way; or between the public and private systems, which have different logics. Also noteworthy is the requirement for a digital signature in the case of a medical prescription made at distance, a practice that is not widespread among Brazilian doctors, despite being regulated by the Federal Pharmacy Council since $2011^{53}$.

\section{Doctor-patient relationship}

A research was carried out in the United Kingdom using the Roter Interaction Analysis System (RIAS), a methodology that allows analyzing conversations during medical consultations, considering three categories: task-focused speech (e.g., application of medical knowledge for diagnosis, treatment and advice), speech and socio-emotional behavior (e.g. greetings, showing concern, etc.) and process-related speech (e.g., inviting the patient to sit down). In the case of this analysis of teleconsultations by video, a fourth category was added regarding the technology used. This research compared the speech and behavior of doctors and patients between teleconsultations and face-to-face consultations, for the same clinical conditions and when appropriate to patients, identifying that in both cases these factors are very similar, with the exception of the speeches regarding adjustments or technological problems, which occurred only in teleconsultations. Moreover, teleconsultations were slightly shorter, with a greater chance of patient speech. Both doctor and patient, at times, needed to make explicit things that were normally implicit in an face-to-face consultation, because they did not share the same physical environment. The importance of having a previous relationship of trust between doctor and patient was emphasized ${ }^{29}$.

This last statement corroborates the mandatory assumption of a previous face-to-face relationship between doctor and patient presented in CFM Resolution N. 2.227/2018 ${ }^{9}$. There is no evidence to justify the adoption of teleconsultation for new patients, but researches demonstrate the willingness of patients to virtually connect with their primary care doctor ${ }^{51}$ and the beneficial effects of teleconsultation seem to be related to its utilization with a known doctor ${ }^{29,41}$. This reinforces the need for continuity of care, which is also important for patients ${ }^{15}$, in addition to the need to explore flexible ways to meet people's needs and improve access.

However, doubts remain regarding the exclusion of this assumption for assistance coverage in geographically remote areas exposed in the resolution. It is not clear how these areas are defined, how to guarantee technological support for teleconsultations in these places, or how the patient's physical examination will be performed. In the United States, the requirement for a face-to-face consultation prior to the teleconsultation aims to ensure the accuracy of the diagnosis. For an exception to the rule, the patient must be examined by the doctor who referred the patient to the specialist or in a clinic or pharmacy equipped for diagnosis. If the patient already knows the doctor, the entire interaction will be less subject to the errors that the virtual element can bring in ${ }^{48}$.

From this perspective, the inability to perform the physical examination is the main disadvantage of the video consultation ${ }^{26,28}$. On the other hand, a study carried out in Australia indicated that this should not be an impediment, since general practice, cardiology and neurology are among the five specialties that use video teleconsultation the most and are the ones that depend the most on physical examination ${ }^{25}$.

Another study carried out in Japan compared face-to-face diagnosis to that performed by video on the first visit to a hospital and concluded that video diagnosis can provide the same level of accuracy for adult patients, as long as there are trained technicians to assist in physical examination and electronic equipment, such as stethoscopes and high definition cameras, developed for examining cavities and organs ${ }^{45}$. The resolution does not report the need for the presence of other professionals to assist with physical examination or diagnosis when providing care in remote areas. It just states that, if this is the case, these professionals should receive adequate training under the responsibility of the doctor or technical director of the intermediating company'.

The acceptability of video teleconsultations by patients and health professionals is not clear due to the limited data reported for this analysis ${ }^{27}$. However, there is a set of organizational, professional and contextual requirements to be met when considering alternatives for face-to-face consultations ${ }^{17}$. For the teleconsultation to be successful, there must be an integration of health care providers, organizations and professionals, in a new way of offering health services, depending on the clinical adequacy and patient preference ${ }^{33}$, planning to maximize their potential for success, with the possibility of service redesigning ${ }^{33,36}$ and the development of new models of care. In fact, its effectiveness depends on whom the service was designed for, the function of the intervention, the health service provider and the system involved in providing the intervention ${ }^{27}$.

\footnotetext{
$10 \mid$\begin{tabular}{l|l} 
REVISTA BRASILEIRA DE EDUCAÇÃO MÉDICA \\
44 (1) : e002; 2020
\end{tabular}
} 


\section{FINAL CONSIDERATIONS}

Different means of communication and information technologies have been applied internationally to mediate the doctor-patient relationship, including telephone, e-mail, electronic consultation systems, video or a combination of these. They can be used in an additive, alternative or partially substitutive way to face-to-face treatment, for diagnosis, counseling, prescription, treatment and monitoring of acute or chronic conditions.

However, the safe and effective implementation of the teleconsultation depends on many factors, despite the claims of its benefits and the questions resulting from the publication of CFM Resolution N. 2,227/2018, authorizing its utilization inside the national territory. In this context, it seems that the public system has some facilitators for the implementation of teleconsultation: it is closer to the implementation of a national electronic medical record, operating with great coverage of Primary Care as a care coordinator and with telemedicine and telehealth systems already developed and operating in safe environments.

Although most of the studies cited in this article have been published in the United Kingdom - which has a public health system that integrates users and services, with security procedures and access restricted to registered professionals and units - it is not possible to transpose the experiences of this scenario into our reality in Brazil. There are differences regarding the electronic integration of the offered services, the geographic distribution of doctors, the dimensions of territorial coverage, the forms of funding the system, the needs of the treated population, the local technological development, among others.

Despite the evidence of the benefits and limitations observed, it seems that the political and corporate challenges are the ones that have the greatest power to prevent the research and development of teleconsultation. Additionally, the health system organization will only undergo significant changes in response to the growing population demand for this service, which is already a reality. For this reason, it is important to seek safe and effective formats, applications and circumstances in which teleconsultation can be beneficial for patient care, considering not only clinical outcomes and the impacts of technology on the doctor-patient relationship, but also the changes resulting from work processes and the management scope.

\section{SOURCES OF FUNDING}

The present study was carried out with the support of the Coordination for the Improvement of Higher Education Personnel - Brazil (CAPES) Funding Code 001.

\section{REFERENCES}

1. Corrêa K, Arreguy E, Santos NB. Telemedicina: novos caminhos para os serviços de saúde. In: VII Esocite - Jornadas Latino-Americanas de Estudos Sociais das Ciências e das Teconologias; 2008; Rio de Janeiro, Brasil [access in 29 set. 2018]. Available from: http://www.necso.ufrj. br/esocite2008/textos.html.

2. Garcia Cuyas F, Vazquez N, San Pedro M, Hospedales M. State of the art of the telemedicine. Where are we and what is pending to be done? Med Clin 2018;150(4):150-4.

3. Nilson LG, Maeyama MA, Dolny LL, Boing AF, Calvo MCM. Telessaúde: da implantação ao entendimento como tecnologia social. Rev Bras Tecnol Soc 2018;5:33-47.
4. Schmitz CAA, Gonçalves MR, Umpierre RN, Siqueirab ACS, D’Ávilab OP, Bastos CGM et al. Teleconsulta: nova fronteira da interação entre médicos e pacientes. Rev Bras Med Fam Comunidade 2017;12(39):1-7.

5. Conselho Federal de Medicina. Código de Ética Médica. Diário Oficial da União 11 jan. 1965;1 (2): 96-9 [access in 29 set. 2018]. Available from: https://portal.cfm.org.br/images/stories/documentos/ EticaMedica/codigoeticamedica1965.pdf.

6. Conselho Federal de Medicina. Resolução CFM $\mathrm{n}^{\circ} 1.931$, de 24 de setembro de 2009. Aprova o Código de Ética Médica. 6a versão. Diário Oficial da União 2010 [access in 29 set. 2018]. Available from: https://portal.cfm.org.br/index.php?option=com content\&view $=$ category\&id=9\&Itemid $=122$.

7. Conselho Federal de Medicina. Parecer CFM no 14, de 27 de abril de 2017. Uso do WhatsApp em ambiente hospitalar. Relator: Emmanuel Fortes S. Cavalcanti. Brasília, 2017 [access in 29 set. 2018]. Available from: https:// sistemas.cfm.org.br/normas/visualizar/pareceres/BR/2017/14.

8. Conselho Federal de Medicina. Resolução CFM nº 2.217, de 27 de setembro de 2018. Aprova o Código de Ética Médica. Diário Oficial da União 2018; 211(Seção 1):179.

9. Conselho Federal de Medicina. Resolução CFM no 2.227, de 13 de dezembro de 2018. Define e disciplina a telemedicina como forma de prestação de serviços médicos mediados por tecnologias. Brasília: CFM; 2018.

10. Mendes KDS, Silveira RCCP, Galvão CM. Revisão integrativa: método de pesquisa para a incorporação de evidências na saúde e na enfermagem. Texto Contexto Enferm 2008;17:758-64.

11. Ursi ES, Gavão CM. Prevenção de lesões de pele no perioperatório: revisão integrativa da literatura. Rev Lat Am Enfermagem 2006;14:124-31.

12. Banks J, Farr M, Salisbury C, Bernard E, Northstone K, Edwards $\mathrm{H}$ et al. Use of an electronic consultation system in primary care: a qualitative interview study. Br J Gen Pract 2018;68(666):e1-8.

13. Agnihotri SP, Koralnik IJ. Training for a neurology career in a rare disease: the role of cyberconsults. Ann Neurol 2015;77(5):738-40.

14. Albert SM, Agimi Y, Martich GD. Interest in mental health care among patients making eVisits. Am J Manag Care 2015;21(12):1-6.

15. Atherton H, Brant H, Ziebland S, Bikker A, Campbell J, Gibson A et al. Alternatives to the face-to-face consultation in general practice: focused ethnographic case study. Br J Gen Pract 2018;68(669):e293-300.

16. Atherton H, Pappas Y, Heneghan C, Murray E. Experiences of using email for general practice consultations: a qualitative study. Br J Gen Pract 2013;63(616):e760-7.

17. Atherton $\mathrm{H}$, Ziebland $\mathrm{S}$. What do we need to consider when planning, implementing and researching the use of alternatives to face-to-face consultations in primary healthcare? Digit Health 2016;2:1-13.

18. Ballesteros SLF, Granja NG, Carrasco MH, Benito AH, Álvarez IG, Ramnón EG et al. La consulta no presencial como herramienta de mejora de la consulta a demanda en atención primaria. Semergen 2018;44(7):458-62.

19. Bertelsen P, Stub Petersen L. Danish Citizens and General Practitioners' Use of ICT for their Mutual Communication. Medinfo 2015;216:376-79.

20. Bishop TF, Press MJ, Mendelsohn JL, Casalino LP. Electronic communication improves access, but barriers to its widespread adoption remain. Health Aff 2013;32(8):1361-67.

21. Brant H, Atherton H, Ziebland S, McKinstry B, Campbell JL, Salisbury C. Using alternatives to face-to-face consultations: a survey of prevalence and attitudes in general practice. Br J Gen Pract 2016;66(648):e460-6.

22. Cowie J, Calveley E, Bowers G, Bowers J. Evaluation of a digital

$11 \mid$\begin{tabular}{l|l} 
REVISTA BRASILEIRA DE EDUCAÇÃO MÉDICA \\
44 (1) : e002; 2020
\end{tabular} 
consultation and self-care advice tool in primary care: a multimethods study. Int J Environ Res Public Health 2018;15(5):e896.

23. Drago A, Winding TN, Antypa N. Videoconferencing in psychiatry, a meta-analysis of assessment and treatment. Eur Psychiatry 2016;36:29-37.

24. Edwards HB, Marques E, Hollingworth W, Horwood J, Farr M, Bernandr $\mathrm{E}$ et al. Use of a primary care online consultation system, by whom, when and why: evaluation of a pilot observational study in 36 general practices in South West England. BMJ Open 2017;7(11):e016901.

25. Fatehi F, Armfield NR, Dimitrijevic M, Gray LC. Clinical applications of videoconferencing: a scoping review of the literature for the period 2002-2012. J Telemed Telecare 2014;20(7):377-83.

26. Ferreira D. Teleconsultas: ir ao hospital sem sair de casa - implicações na relação médico-doente. Medicina Interna 2018;25(1):10-4.

27. Flodgren G, Rachas A, Farmer AJ, Inzitari M, Shepperd S. Interactive telemedicine: effects on professional practice and health care outcomes. Cochrane Database Syst Rev 2015(9):Cd002098.

28. Frade S, Rodrigues H. Benefits, challenges and impact of teleconsultation - a literature review. Stud Health Technol Inform 2013;192:1157.

29. Greenhalgh T, Shaw S, Wherton J, Vijayaraghavan S, Morris J, Bhattacharya $S$ et al. Real-world implementation of video outpatient consultations at macro, meso, and micro levels: mixed-method study. J Med Internet Res 2018;20(4):e150.

30. Hickey S, Gomez J, Meller B, Schneider JC, Cheney M, Nejad S et al. Interactive home telehealth and burns: a pilot study. Burns 2017;43(6):1318-21.

31. Hoek PD, Schers HJ, Bronkhorst EM, Vissers KCP, Hasselaar JGJ. The effect of weekly specialist palliative care teleconsultations in patients with advanced cancer: a randomized clinical trial. BMC Medicine 2017;15(1):119.

32. Iacobucci G. Stop rollout of online consultations until there is evidence of benefit to patients, say LMCs. BMJ 2017;359:j5247.

33. Jury SC, Kornberg AJ. Integrating telehealth in to "business as usual": is it really possible? J Telemed Telecare 2016;22(8):499-503.

34. Kew KM, Cates CJ. Remote versus face-to-face check-ups for asthma. Cochrane Database Syst Rev 2016;18(4):Cd011715.

35. Ladino MA, Wiley J, Schulman IH, Sabucedo AJ, Garcia D, Cardona JM et al. tele-nephrology: a feasible way to improve access to care for patients with kidney disease who reside in underserved areas. Telemed J E Health 2016;22(8):650-4.

36. LeRouge CM, Garfield MJ, Hevner AR. Patient perspectives of telemedicine quality. Patient Prefer Adherence 2015;9:25-40.

37. Lipana LS, Bindal D, Nettiksimmons J, Shaikh U. Telemedicine and face-to-face care for pediatric obesity. Telemed J E Health 2013;19(10):806-8.

38. Liston A. GP access - time for a radical solution? Br J Gen Pract 2013;63(614):483.

39. Liu W, Saxon DR, McNair B, Sanagorski R, Rasouli N. Endocrinology telehealth consultation improved glycemic control similar to face-toface visits in veterans. J Diabetes Sci Technol 2016;10(5):1079-86.

40. McCartney M. General practice can't just exclude sick people. BMJ 2017;359:j5190.

41. McGrail KM, Ahuja MA, Leaver CA. Virtual visits and patient- centered care: results of a patient survey and observational study. J Med Internet Res 2017;19(5):e177.

42. McLean S, Sheikh A, Cresswell K, Nurmatov U, Mukherjee M, Hemmi A et al. The impact of telehealthcare on the quality and safety of care: a systematic overview. PLoS One 2013;8(8):e71238.

43. Moth G, Huibers L, Christensen MB, Vedsted P. Drug prescription by telephone consultation in Danish out-of-hours primary care: a population-based study of frequency and associations with clinical severity and diagnosis. BMC Fam Pract 2014;15:142.

44. Newbould J, Abel G, Ball S, Corbert J, Elliott M, Exley J et al. Evaluation of telephone first approach to demand management in English general practice: observational study. BMJ 2017;358:j4197.

45. Ohta M, Ohira Y, Uehara T, Keira K, Noda K, Hirukawa M et al. How accurate are first visit diagnoses using synchronous video visits with physicians? Telemed J E Health 2017;23(2):119-29.

46. Plener I, Hayward A, Saibil F. E-mail communication in the management of gastroenterology patients: a review. Can J Gastroenterol Hepatol 2014;28(3):161-5.

47. Poulsen KA, Millen CM, Lakshman UI, Buttner PG, Roberts LJ. Satisfaction with rural rheumatology telemedicine service. Int J Rheum Dis 2015;18(3):304-14.

48. Rosenzweig R, Baum N. The virtual doctor visit. J Med Pract Manage 2013;29(3):195-8.

49. Sabesan S, Allen D, Loh PK, Caldwell P, Mozer R, Komesarof PA et al. Practical aspects of telehealth: are my patients suited to telehealth? Intern Med J 2013;43(5):581-4.

50. Torjesen I. The private, online GP will see you now. BMJ 2016;352:i823.

51. Welch BM, Harvey J, O'Connell NS, McElligott JT. Patient preferences for direct-to-consumer telemedicine services: a nationwide survey. BMC Health Serv Res 2017;17(784):1-7.

52. Young AJ. New technologies and general practice. Br J Gen Pract 2016;66:601-2.

53. Conselho Federal de Farmácia. Resolução CFF no 555, de 30 de novembro de 2011. Regulamenta o registro, a guarda e o manuseio de informações resultantes da prática da assistência farmacêutica nos serviços de saúde. Diário Oficial da União 2011.

\section{AUTHORS' CONTRIBUTION}

Soraia de Camargo Catapan contributed to the conception and design of the study, analysis and interpretation of the results and writing of the manuscript. Maria Cristina Marino Calvo contributed to the design and planning of the study, critical review of the content at all stages of the analysis of the results and approval of the final version of the manuscript.

\section{CONFLICTS OF INTEREST}

The authors declare no conflicts of interest.

\section{ADDRESS FOR CORRESPONDENCE}

Departamento de Saúde Pública. Programa de Pós-Graduação em Saúde Coletiva. Campus Universitário, Rua Delfino Conti, Bloco H, Trindade. CEP: 88040-900. Florianópolis/SC, Brasil.

E-mail: scatapan@gmail.com. 